\title{
Analyzing the Market for Shadow Education in Pakistan: Does Private Tuition Affect the Learning Gap between Private and Public Schools?
}

\author{
Bisma Haseeb Khan* and Sahar Amjad Shaikh**
}

\begin{abstract}
Over the past decade, Pakistan has seen the rapid growth of a third sector in education: shadow education. According to the Annual Survey of Education Report (2013), 34 percent of private school students and 17 percent of public school students undertake private tuition in Punjab. Anecdotal evidence suggests that private tuition has a positive impact on learning outcomes. Keeping this in view, it is possible that private tuition, rather than a difference in schooling quality, is driving the observed learning gap between public and private schools? This study employs a fixed-effects framework, using panel data from the Learning and Educational Achievement in Punjab Schools (LEAPS) survey, to quantify the impact of private tuition on learning outcomes in public and private schools. We analyze the demand and supply dynamics of the shadow education market in Punjab, and find that private tuition has a positive significant effect on learning outcomes, specifically for public school students. For English, much of the learning gap between public and private schools is explained by the higher incidence of private tuition among private school students, but this is not the case for mathematics and Urdu. We also find that private tuition is predominantly supplied by private school teachers, but that they do not shirk their regular class hours to create demand for their tuition classes, as is normally believed. On the demand side, private tuition acts as a substitute for receiving help at home. Moreover, it supplements formal education rather than substituting for low-quality formal schooling.
\end{abstract}

Keywords: Public versus private education, education quality, tutoring, Pakistan.

JEL classification: I00, I21, I28.

\section{Introduction}

The growth of low-fee private schools in Pakistan has changed the dynamics of the country's education sector. According to the literature,

\footnotetext{
${ }^{*}$ Research Associate, Institute for Development and Economic Alternatives (IDEAS), Pakistan.

*** Teaching Fellow, Lahore University of Management Sciences (LUMS), Pakistan.
} 
private schools outperform public schools in terms of learning outcomes (Aslam, 2009; Andrabi, Das, \& Khwaja, 2002). This learning gap raises concerns about the standard of education provided by public schools and the associated equity effects, and led to serious debate on the relationship between education expenditure and academic performance.

Existing studies have, however, largely ignored a third emerging sector in education: shadow education. Shadow education is defined as extra, paid private tuition classes given after school hours, either one-toone at the student's home or in larger groups or at tuition academies. Evidence shows the growing prevalence of such classes in Pakistan with approximately 11 percent of students in rural areas and 54 percent in urban areas opting for private tuition. Moreover, a higher proportion of private school students are found to engage in private tuition than government school students (Annual Status of Education Report, 2013).

Keeping this in view, it is possible that private tuition, rather than a difference in schooling quality, is driving the observed learning gap between public and private schools. The literature on Pakistan is silent in this regard, and the international literature on shadow education provides mixed evidence on the impact of private tuition on academic performance. There is a dearth of research examining the demand and supply of private tuition classes, leaving a number of questions open to debate, particularly in the context of less developed countries.

This paper attempts to fill these gaps in the literature by examining the dynamics of the private tuition market in Punjab, Pakistan. We analyze the impact of private tuition on academic performance, looking particularly at whether it can explain the observed learning gap between public and private schools and whether private tuition can help bridge this gap. On the demand side, we analyze whether private tuition serves as a substitute for low-quality formal schooling or supplements in-school learning, and if it acts as a substitute for help received at home. On the supply side, we identify the main providers of private tuition and determine whether the mainstream schoolteachers that provide private tuition do so at the cost of in-school teaching.

The initial descriptive analysis examines the characteristics of private tutors and their tutees. The literature suggests a variety of reasons for the upspring of private tuition classes: a corrupt public schooling system where teachers are poorly monitored and shirk their classes, forcing students to undertake paid tuition after school (Gurun \& Millimet, 2008); a 
supplement to quality education used to gain an edge over other students; or a form of remedial classes for low-performing students.

In the case of Punjab, our descriptive analysis suggests that private tuition is, in fact, a supplement undertaken by already high-achieving students. Further, private school teachers and students are more likely to engage in these classes than public school students. This suggests that the private tuition phenomenon does not necessarily result from poor-quality public schools. The analysis also indicates that private tuition serves mainly as a substitute for help received at home. A random-effects analysis using data from the Learning and Educational Achievement in Punjab Schools (LEAPS) panel, confirms these findings.

We also examine the switchers in our sample (those who take up private tuition during the period of analysis) in a gains formulation, looking at the value that a year's private tuition adds to a student's learning outcomes. Fixed-effects estimation is carried out to account for possible endogeneity in the regression equation caused by unobserved, time-invariant, individual-specific variables that affect both tuition uptake and student performance. The model is fitted separately for private and public school students (those who did not switch schools during the survey period) in order not to confound the effect of private tuition with that of switching between schools.

Our findings suggest that private tuition has a positive impact on academic performance, specifically for public school students. The effect differs by subject. For mathematics and Urdu, the learning gap between public and private schools remains even after accounting for private tuition, but can be bridged by providing more such tuition classes to public school students. In English, the gap is significantly reduced once tuition is controlled for as private tuition significantly affects private school students' performance (but not that of public school students in this case).

The relationship between academic achievement and private tutoring calls into question the level of effort of private school teachers (the main providers of these tuition classes) during school hours. If teachers are deliberately shirking their duties during school hours to force their students to undertake these extra classes, then private tuition can be said to reduce welfare. If this is not the case and such classes enhance learning in addition to regular schooling, then a case can be made for regulating and even encouraging this sector; a combination of free public schooling and private tuition would benefit parents who cannot afford to send their children to private schools. Our findings suggest the latter: based on observable 
characteristics measuring teacher effort in class, we find no significant difference between teachers who provide tuition and those who do not.

The remaining paper is organized as follows: Section 2 provides a brief overview of the literature; Section 3 looks at the dataset used in this study and provides a descriptive analysis of the private tuition sector. Section 4 explains the empirical strategy used in the regression analysis and Section 5 gives the results of this analysis. Section 6 discusses the main findings and concludes the paper.

\section{Literature Review}

With the rising privatization of education and upspring of low-fee private schools in Pakistan, a vast body of literature has emerged looking at the impact of private schools on students' academic performance. Most studies on Pakistan find a positive and significant learning gap between private and public schools (Andrabi, Khwaja, Zajonc, \& Vishwanath, 2007). The international literature attributes much of the difference in educational outcomes among students to factors such as their socioeconomic background and parental education (Lloyd, Mete, \& Sathar, 2005).

In the context of Pakistan, the learning gap between private and public schools overrides any differences attributed to such factors (Andrabi et al., 2002; Andrabi et al., 2007). According to Das, Pandey, and Zajonc (2006), the private-public learning gap is 12 times as large as that between rich and poor students and five times the gap between literate and illiterate mothers. This gap is explained in terms of differences in school quality with low-quality public schooling attributed to the lack of monitoring and accountability of public school teachers and to high teacher absenteeism (Aslam, 2003). However, these studies fail to account for a rapidly emerging third sector: shadow education. Despite the high incidence of private tuition in Pakistan, there is limited evidence on the determinants of private tuition and its impact on academic performance, particularly whether it might explain the learning gap between private and public schools.

The international literature indicates two types of demand for private tuition: (i) as remedial education for low-performing students (Jacob \& Lefgren, 2004), and (ii) as additional help for high-performing students to give them an advantage over their counterparts (Dang \& Rogers, 2008). Both types are growing all around the world, including economically and culturally diverse countries such as the US, Cambodia, Vietnam, Japan, India, and South Africa (Dang \& Rogers, 2008). Even within countries, private tuition is not just the preserve of the rich living in 
urban areas, it is also evident in rural areas among less well-off families (Asankha, 2011). Neither is it limited to higher levels of schooling: in some countries, even preschool students undertake private tuition (Watson, 2008). Nevertheless, income and living in urban areas are found to be positively associated with private tuition uptake (Bray \& Lykins, 2012).

Other factors positively associated with the demand for private tuition include parental education, class level, low-quality public schooling, and the institution of competitive exams at different levels of education, including exams for university placement (Kang, 2007; Barro \& Lee, 2010; Glewwe \& Kremer, 2006). Household size, on the other hand, negatively affects the demand for private tuition (Tansel \& Bircan, 2006). Some parents invest in private tuition classes to better their children's learning and consequent labor market outcomes. They feel that the longer their child stays in the education system and the better the quality of that education, the greater will be the prospects of enhanced lifetime earnings for that child (Bray \& Lykins, 2012). On the other hand, some parents send their children to private tuition classes merely due to peer pressure (in certain cultures, it is even considered prestigious) and not because of any perceived learning benefits (Bray, 2007).

Much less work has been done on the supply side of private tuition and thus little is known about those who provide such tuition. The literature identifies different types of private tuition supply, ranging from one-to-one study sessions at the student's house to larger classes held at tuition academies specifically set up for this purpose (e.g., the juku in Japan) (Bray \& Silova, 2006). Tutors themselves also vary in age, training, socioeconomic background, and other characteristics. In most countries, poorly paid classroom teachers provide private tuition to supplement their meager earnings (Dawson, 2009; Benveniste, Marshall, \& Santibañez, 2008). At other times, mainstream teachers force tuition on their students by deliberately leaving out parts of the curriculum during regular school hours and covering it in private tuition classes. Thus, when teachers provide private tuition to their own students, it might have a detrimental effect on mainstream schooling. University students or retired teachers may also engage in tuition to supplement their income (Bray, 2007).

Finally, the consequences of private tuition in terms of its impact on academic performance are also ambiguous. The literature provides mixed results ranging from a positive, significant effect on academic performance (Ha \& Harpham, 2005) to an insignificant effect (Lee, Kim, \& Yoon, 2004). Some studies even find it has a negative effect on learning outcomes. For 
instance, Cheo and Quah (2005), looking at secondary school students in Singapore, find that private tuition has a negative, significant impact on academic performance. They attribute this to the overburdening of students, resulting in negative marginal utility from private tuition.

In some cases, private tuition uptake might not affect academic performance, but higher expenditure on private tuition conditional on undertaking tuition may lead to increased academic performance. For instance, Gurun and Millimet (2008) find that, in Turkey, private tuition uptake has a negative effect on university placement while higher expenditure on tuition conditional on its uptake has a positive, significant impact on university placement. These results should, however, be interpreted with caution: treating expenditure on private tuition as exogenous is suspect because unobserved factors such as motivation and the child's ability can affect both private tuition uptake and academic performance, leading to endogeneity in the regression equation.

Such endogeneity can be controlled for either by conducting a randomized control trial or using other statistical techniques such as fixedeffects estimation using panel data or instrumental variable analysis. Most studies rely on the instrumental variable approach; commonly used instrumental variables include the tutoring fees charged in an area (Dang, 2007) and whether a child is firstborn (Kang, 2007). In the case of Vietnam, Dang finds that private tuition has a positive significant impact on reading ability but an insignificant impact on arithmetic test scores. Kang finds a similar result and uses parametric bounds to test the sensitivity of the findings. Again, these results should be interpreted with caution because they do not control for the type of private tuition undertaken (one-to-one or in larger classes). Different types of tuition can affect academic performance in different ways.

To our knowledge, no study to date has assessed the impact of private tuition on academic performance, particularly the learning gap between public and private schools in Punjab, while controlling for possible endogeneity. We seek to fill this gap by analyzing the determinants of private tuition and using the fixed-effects approach to quantify its impact on academic performance in rural Punjab.

\section{Data and Descriptive Statistics}

This section describes and analyzes the dataset used. 


\subsection{Data}

The LEAPS survey provides a rich and unique dataset for the purposes of this study. It is a panel dataset collected for the years 2003, 2004, and 2005 and is unique in that it combines information from household surveys, school surveys, and tests scores for rural areas of Punjab. The LEAPS dataset spans three districts from distinct regions: Attock in northern Punjab, Faisalabad in central Punjab, and Rahimyar Khan in southern Punjab. Within these districts, 112 villages were randomly selected from a subset of villages that had a private school. It surveyed and tested approximately Grade 3 students in 2003 and followed them over time, testing them again in 2004 and 2005.

Our sample comprises children on whom information was available for all three years on test scores, and school-level and householdlevel characteristics. In 2003, 12,000 children were tested from a representative sample of 838 public and private schools. Based on the household survey data, we can gauge for each child his/her family's socioeconomic status, whether he/she undertook private tuition in a given year, the type of school he/she attends, parental literacy, health status, and parents' perceptions of various dimensions of their child's schooling, such as child quality (whether he/she is hardworking and intelligent) and the class teacher's level of absenteeism and teaching skills.

The school survey provides information on school-level variables for the child's school, in particular student-teacher ratios (STRs), teacher absenteeism, and the provision of basic infrastructure and amenities. The LEAPS data gauges educational achievement by testing students in three subjects: mathematics, Urdu, and English. The results are then evaluated using item response theory and standardized to give z-scores.

On the supply-side investigation of the private tuition market, the survey's unit of analysis is the teacher. In the descriptive analysis, we find that private tuition is mainly provided by mainstream schoolteachers. Using the data on whether or not a teacher provides private tuition (available from the school survey), we develop a detailed profile of who supplies these private tuition classes in rural Punjab. The variables available in the teacher roster include the type of school the teachers teach at, their monthly earnings from teaching, years of teaching experience, nature of contract (relevant for public school teachers), incentive structure, and other characteristics (gender, marital status). 


\subsection{Descriptive Statistics}

\subsubsection{The Demand Side}

This section provides an insight into the dynamics of the demand for private tuition. The incidence of private tuition is higher among private school children compared to those enrolled in public schools. However, this changes in our sample over time: in 2003, 27 percent of private school students and 15 percent of public school students were undertaking private tuition; in 2005, the corresponding figures had changed to 20 percent for private school students and 19 percent for public schools students (see Figure 1). However, this could also be because of the changing publicprivate school composition in our sample. Figure 2 shows the relationship between private to public school switching and private tuition uptake.

Most students that shifted from public to private schools during the period of analysis did not report undertaking private tuition (71 percent in 2004 and 60 percent in 2005). Students who switched from private to public schools, on the other hand, were either already engaged in private tuition (32 percent in 2005) or started once they had shifted to public schools (40 percent in 2004 and 20 percent in 2005). This implies that students who shift from private to public schools supplement any consequent loss in learning (due to the perceived lower quality of public schooling) by taking up private tuition.

Figure 1: Private tuition incidence over time

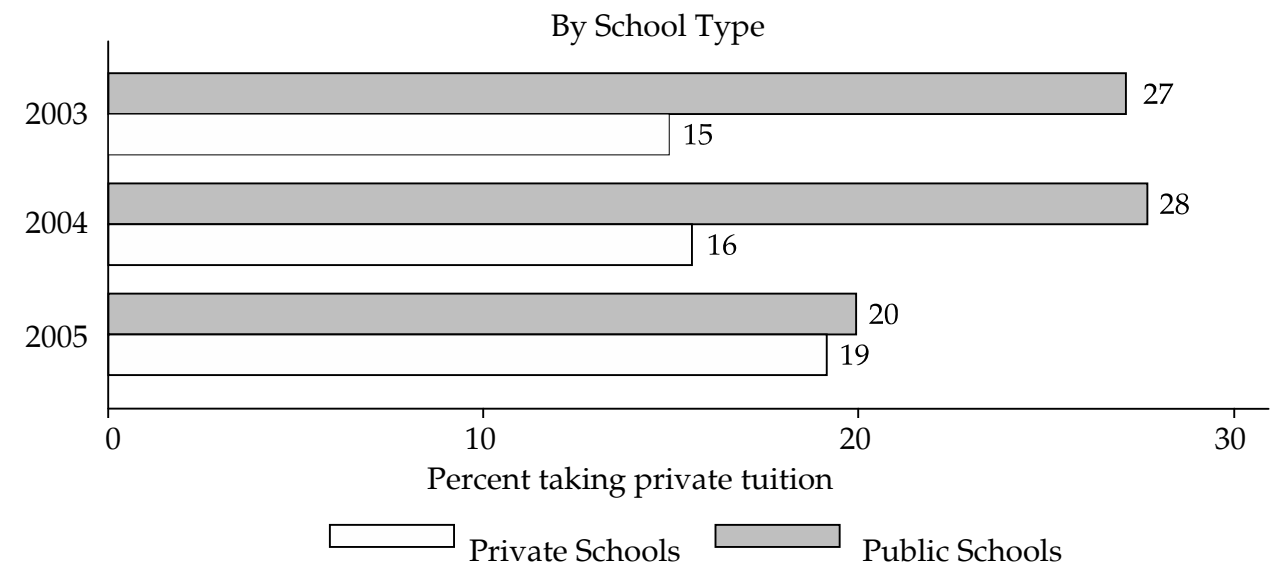

Source: LEAPS Data 2003 - 2005 
Figure 2: Private tuition uptake and school switchers
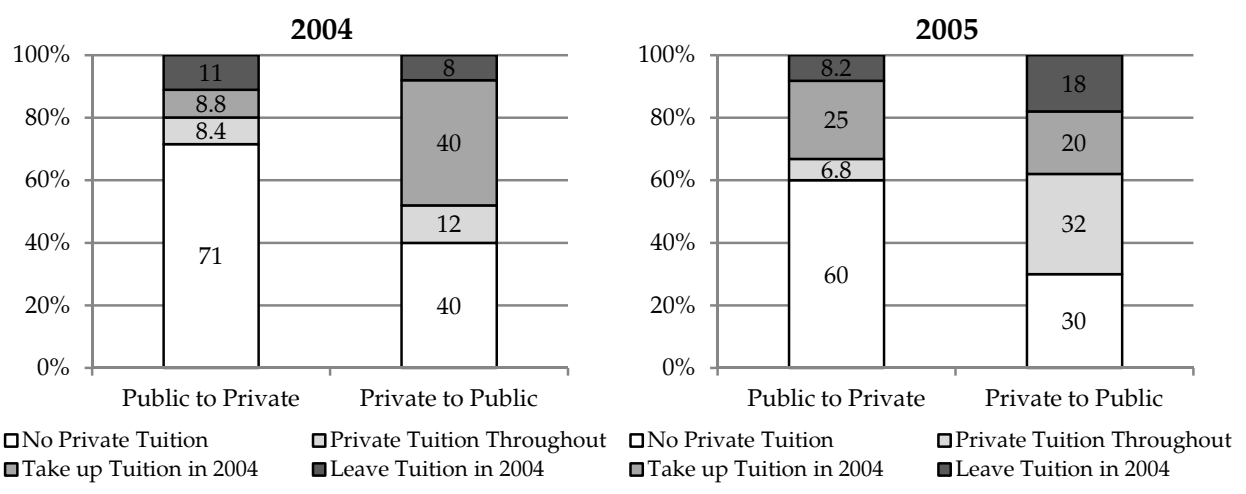

Source: LEAPS Data 2003 - 2005

Conditional on engaging in private tuition, the expenditure on such classes is not significantly different for private and public school students in 2003 and 2004 (see Figure 3). However, in 2005, there is a statistically significant difference between public and private school students' expenditure on tuition classes conditional on undertaking tuition. ${ }^{1}$ This suggests that, even though the difference in the incidence of private tuition between public and private schools decreased in 2005, there might be a difference in the quality of the private tuition (as indicated by its cost) undertaken by these two categories of students. The average time in a week spent on private tuition, on the other hand, remains comparable across school type and over time, with students spending approximately 12 hours on average engaged in tuition classes each week.

\footnotetext{
${ }^{1}$ Figure 3 shows the expenditure figures, but the results of the t-test are not given due to space constraints.
} 
Figure 3: Monthly expenditure and weekly time spent on private tuition

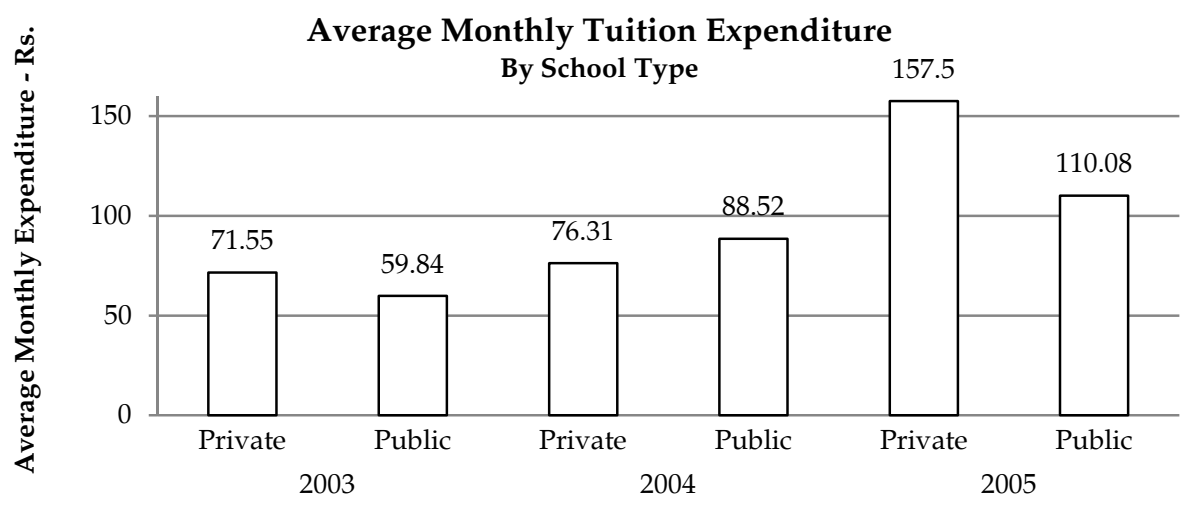

Time Spent on Private Tuition Last Week

By School Type

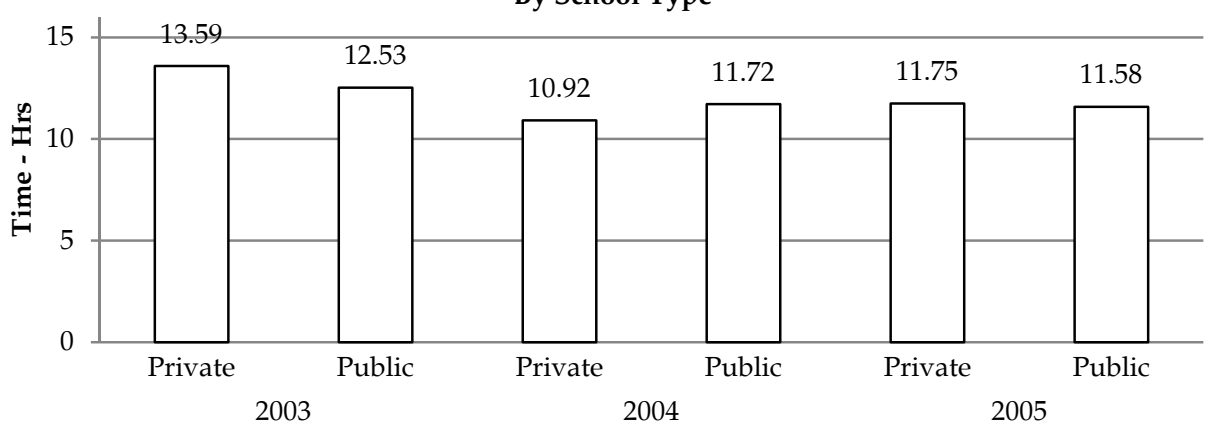

Source: LEAPS Data 2003 - 2005

Not surprisingly, we find that private tuition is sought less when the child is receiving help at home. The uptake of private tuition is approximately 10 percent lower for public school students who receive help with their schoolwork at home, and approximately 20 percent lower for private school students who receive help at home (see Figure 4). This difference remains steady over time. 
Figure 4: Help received at home and private tuition uptake

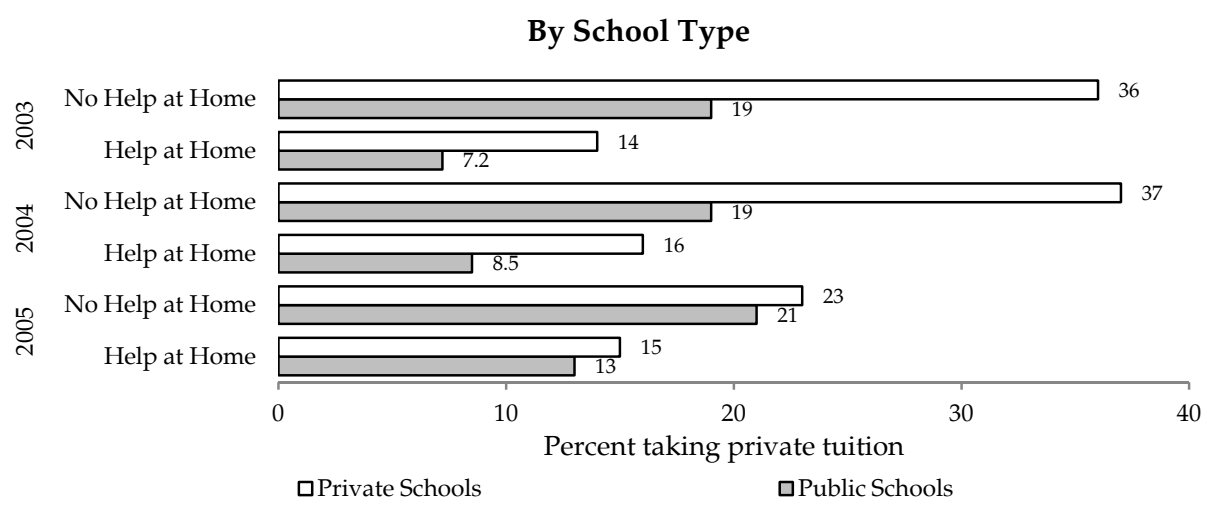

Source: LEAPS Data 2003 - 2005

Interestingly, the distribution of private tuition for both types of schools is skewed toward students who are perceived by their parents to have average or above-average intelligence (see Figure 5). This trend holds over time, suggesting that private tuition is not a form of remedial education; rather, it is sought by parents to supplement the performance of children whom they perceive as capable of doing well.

Figure 5: Distribution of tutees by perceived intelligence

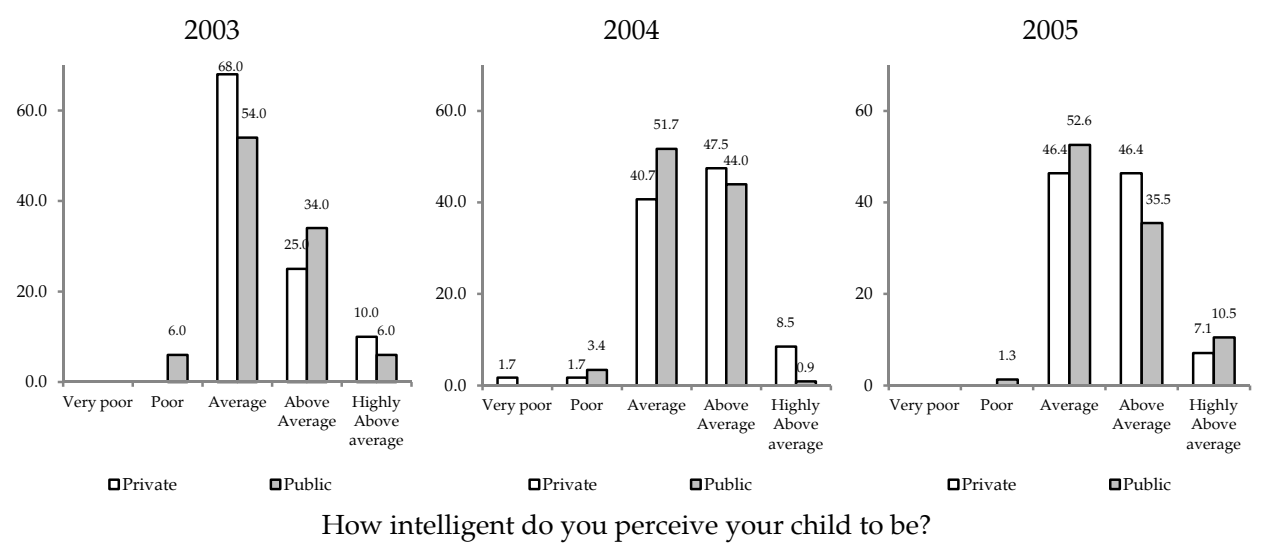

Source: LEAPS Data 2003 - 2005

Last, we look at who these tutors are. Figure 6 shows the distribution of private tutors to public and private school students. In both cases, private tuition is provided mainly by mainstream teachers, with this trend increasing over time. In private schools, most of these teachers belong to the student's own school; in public schools, they tend to be from other schools. 
Figure 6: Who provides private tuition?

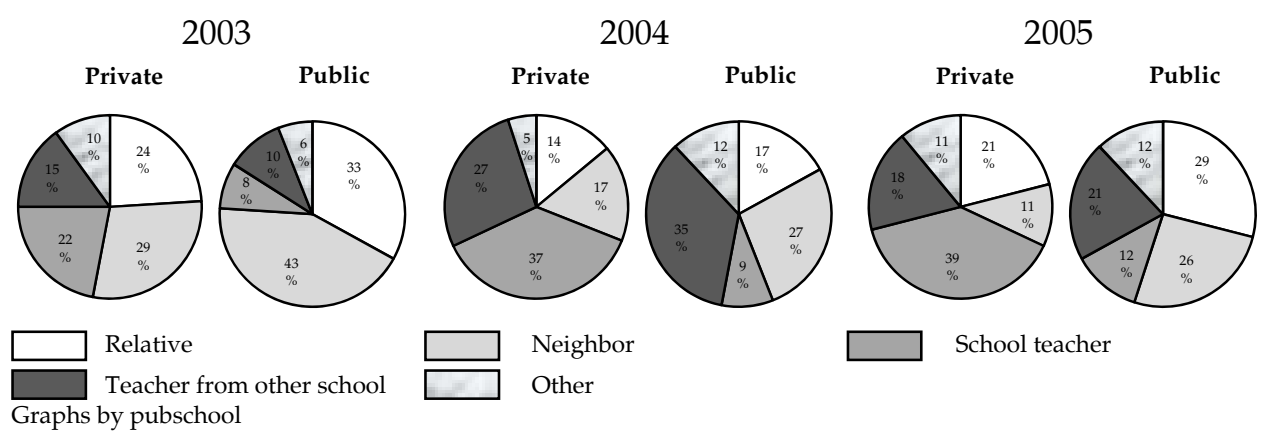

Source: LEAPS Data 2003 - 2005

\subsubsection{The Supply Side}

In the analysis of private tuition, it is also critical to investigate the factors determining its supply. As shown above, schoolteachers are the main providers of private tuition. This section reports descriptive statistics on these mainstream teachers, providing a comprehensive profile of those who decide to engage in the private tuition market.

Figure 7 shows that private school teachers engage in private tuition far more than their public school counterparts, with this difference increasing over time. This, taken in conjunction with the above result, suggests that private school students generally undertake tuition from their own teachers whereas public school students engage private school teachers. This leads to the concern that these private school teachers may be shirking their duties during formal school hours, forcing their students to take extra classes with them after school.

Figure 7: Private tuition incidence over time

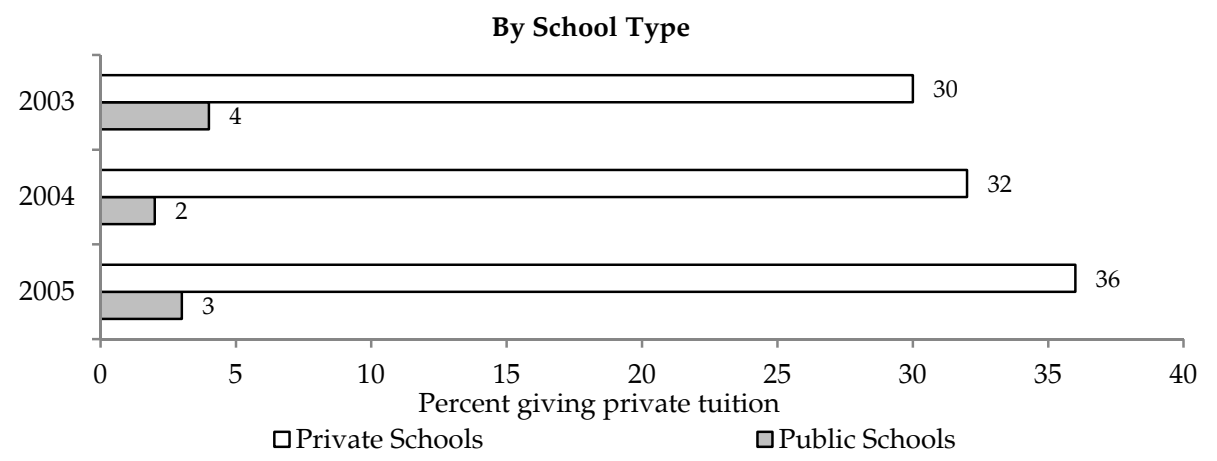

Source: LEAPS Data 2003 - 2005 
To test this, we compare the mean levels of absenteeism and knowledge scores of tutors and nontutors. These variables measure the observable levels of effort and teacher quality. Figure 8 shows no significant difference in levels of absenteeism and knowledge scores between tutors and nontutors in both types of schools. T-tests performed on these variables over time for both types of schools, support this finding. ${ }^{2}$

\section{Figure 8: Absenteeism and test scores}
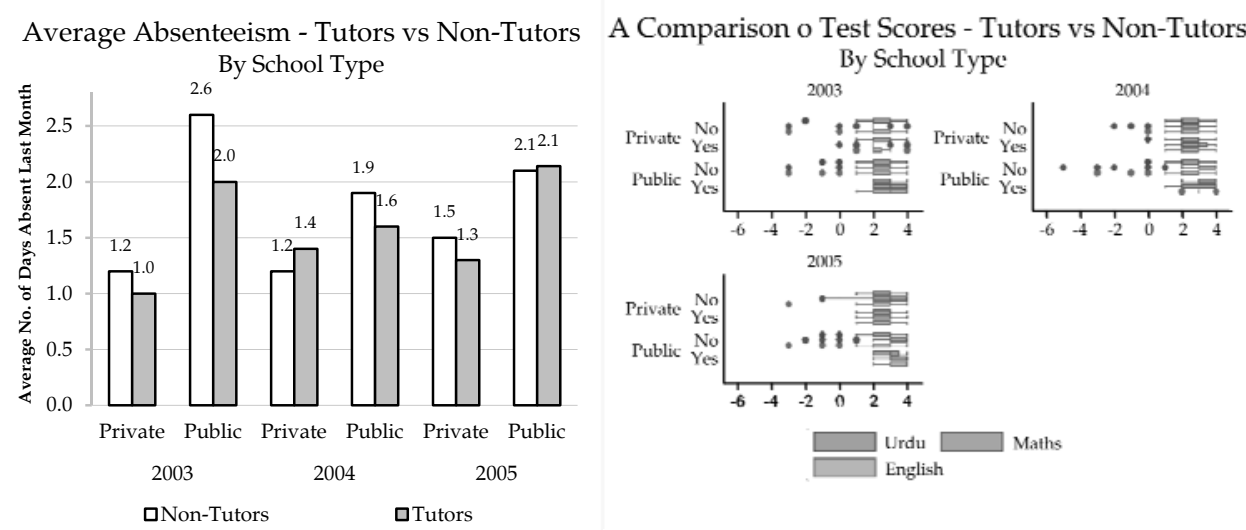

Source: LEAPS Data 2003 - 2005

If not teacher quality, then what explains why some teachers opt to supply private tuition and not others? To investigate this, we compare the nature of employment of tutors and nontutors across school types. Figure 9 shows that teachers with nonpermanent contracts (and hence lower salaries and less job security) are more inclined to provide private tuition than those with permanent contracts. This result, taken together with the finding that a higher proportion of private school teachers provide private tuition (given that they earn less than public school teachers), suggests that low salaries could be why these teachers engage in the private tuition market. Tuition classes are a means to supplement their income from mainstream teaching.

\footnotetext{
${ }^{2}$ The results of the t-tests are not given due to space constraints.
} 
Figure 9: Supply of private tuition by employment status

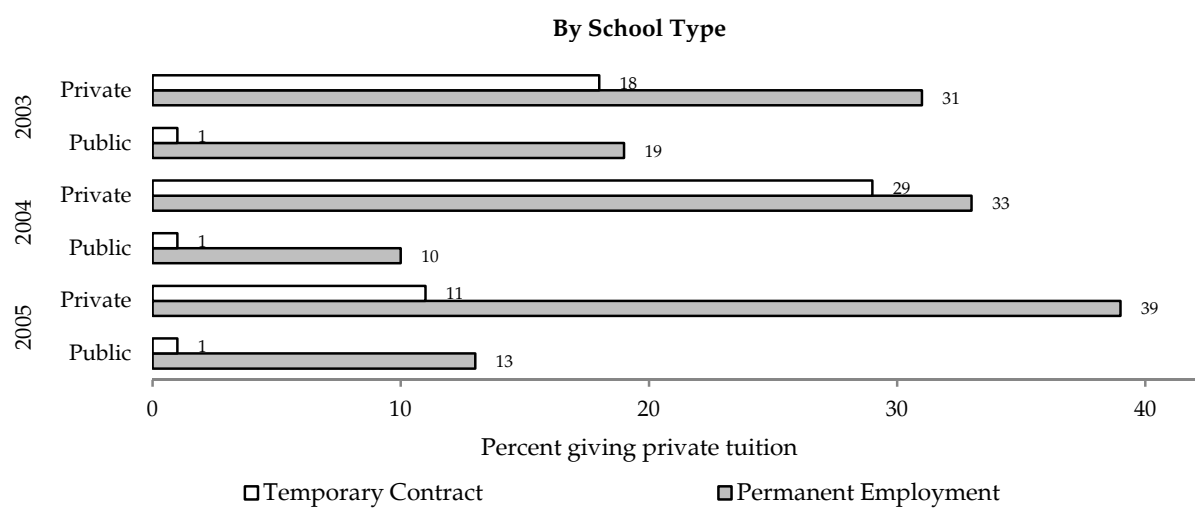

Source: LEAPS Data 2003 - 2005

\section{Empirical Strategy}

The descriptive analysis gives a good picture of the incidence of private tuition in Pakistan and its composition. However, in order to isolate its demand and supply determinants and assess its impact on academic performance, we need to carry out a regression analysis. We estimate three regression models: demand- and supply-side random-effects models for the determinants of private tuition and a fixed-effects probit model for the impact of private tuition on academic performance, estimated separately for public and private schools.

\subsection{Determinants of Private Tuition}

The following model estimates the demand-side determinants of private tuition:

$$
\begin{aligned}
& P_{i t}=\beta_{0}+\beta_{1} \text { pubschool }_{t t}+\beta_{2} \text { hhldwealth }_{t t}+\beta_{3} \text { age }_{i t}+\beta_{4} \text { age }_{i t}^{2}+\beta_{5} \text { female }_{i} \\
& +\beta_{6} \text { helpathom }_{i t}+\beta_{7} X_{i}+\beta_{8} W_{j}+\alpha_{i}+\varepsilon_{i t}
\end{aligned}
$$

$P_{i}$, is a binary variable measuring the incidence of private tuition; $P_{i}$ is equal to 1 if the child undertakes private tuition and 0 otherwise. Here, private tuition is defined as paid after-school classes, and is not restricted to any one type of tuition class (one-to-one, tuition academies, etc.) nor to a particular type of provider (mainstream teacher, village elder, neighbor, etc.). The independent variables include pubschool (a binary variable equal to 1 if the child attends public school and 0 otherwise), hhldwealth (principal components analysis [PCA] wealth index), age, age $e^{\wedge 2}$, female (a binary 
variable equal to 1 if the child is female), and helpathome (a binary variable equal to 1 if the child receives help with his/her schoolwork at home).

The household wealth index is calculated using the LEAPS methodology and is based on household assets rather than income or consumption (Andrabi et al., 2007). ${ }^{3}$ The variables $X_{i}$ and $W_{i}$ are vectors containing other child-level and school-level variables, respectively. The child-level variables include the child's height measured in standard deviations from the mean height for that child's age group (used as a measure of the child's health), class, and parents' perception of the child's intelligence. The two school-level variables measure school quality: the STR and a basic infrastructure index. ${ }^{4}$ These allow us to estimate whether poorquality formal schooling leads to the uptake of private tuition.

The panel nature of the LEAPS data allows us to estimate the above model using random effects to account for any unobserved, time-invariant, child-level characteristics $\left(\alpha_{i}\right)$ that might affect private tuition uptake. We use a random-effects rather than fixed-effects model as we are interested in looking at child-level characteristics that affect private tuition but that might not vary considerably over time, such as the child's gender, household wealth, etc. Fixed-effects estimators absorb these characteristics in the constant term whereas random-effects estimators allow us to account for these time-invariant characteristics. Moreover, using random effects also allows the inferences of the model to be generalized beyond the sample used for the estimation (Wooldridge, 2002).

A random-effects estimator makes the stronger assumption that the unobserved omitted variables are not correlated with the independent variables in the regression equation, and that the independent variables are strictly exogenous, i.e.:

$$
E\left(x_{i t} u_{i s}\right)=0 \text { for } s=1,2, \ldots, t
$$

Under these conditions, the random-effects estimator is both consistent and efficient. A Breusch-Pagan test conducted to test the existence of random effects confirms their presence. As the random-effects model allows us to account for individual heterogeneity while estimating

\footnotetext{
${ }^{3}$ PCA is used to construct the asset index, and includes assets owned by the household.

4 Following Andrabi et al.'s (2007) methodology, the basic infrastructure index is calculated using PCA and measures the number of desks per student, classrooms per student, toilets per student, and the total number of blackboards a school contains. Higher values of the index correspond to better infrastructure.
} 
the impact of time-invariant, individual-level characteristics on private tuition attendance, we fit a random-effects probit model to estimate equation (1). The marginal effects and post-estimation predicted probabilities are then calculated to quantify the magnitude of the impact of the variables of interest on tuition uptake. Village fixed effects and time fixed effects are also accounted for in the model. As a robustness check, the model is re-estimated using a logit model and pooled OLS framework. ${ }^{5}$

The following model estimates the supply-side determinants of private tuition:

$$
\begin{aligned}
& G P_{i t}=\beta_{0}+\beta_{1} \text { pubschool }_{i t}+\beta_{2} \text { lsalary }_{i t}+\beta_{3} \text { age }_{i t}+\beta_{4} \text { age }_{i t}^{2}+ \\
& \beta_{5} \text { absenteeism }_{t}+\beta_{6} \text { experience }_{i t}+\beta_{7} \text { contract }_{i t}+\beta_{8} \text { localteach }_{i t}+ \\
& \beta_{9} \text { decisionmaking }_{t}+\beta_{10} X_{i}+\alpha_{i}+\varepsilon_{i}
\end{aligned}
$$

This model measures the supply of private tuition provided by mainstream teachers and not by other tuition providers, such as village elders or relatives. It does not, however, distinguish between the types of tuition provided. The dependent variable is GP, a dummy variable measuring whether a teacher provides private tuition. The controls included are pubschool (a binary variable measuring whether the teacher teaches at a public school), lsalary (the log of the monthly salary earned by the teacher from his/her regular school), age, age $e^{\wedge 2}$, absenteeism (measures the number of days the teacher was absent in the last month), experience (years of experience as a teacher), contract (a binary variable measuring whether the teacher is a contract teacher or a permanent teacher), localteach (a binary variable measuring whether the teacher lives in the same village in which he/she teaches), and decisionmaking (measures whether the teacher has decision-making power over teaching style and curriculum). $X_{i}$ is a vector containing other teacher characteristics, such as the teacher's gender and marital status.

For the reasons cited above, we apply a random-effects probit model to the teacher data panel to estimate equation (2), and then estimate the marginal effects to quantify the impact of these variables on the decision to offer private tuition. Village fixed effects and time effects are controlled for in the model, and robustness checks are conducted by estimating a logit and pooled OLS model.

\footnotetext{
${ }^{5}$ Results not reported due to space constraints.
} 


\subsection{Impact of Private Tuition on Academic Performance}

We determine the impact of private tuition on academic performance by examining individuals who switched between undertaking tuition and not undertaking tuition over the three rounds of the survey. In order not to confound the impact of private tuition with that of students switching between public and private schools, we estimate the following three equations separately for public and private school students:

$$
\begin{aligned}
& \text { Engscore }=\beta_{0}+\beta_{2} P_{i t}+\beta_{3} X_{i t}+\beta_{4} W_{i t}+\alpha_{i}+\varepsilon_{i t} \\
& \text { Urduscore }=\beta_{0}+\beta_{2} P_{i t}+\beta_{3} X_{i t}+\beta_{4} W_{i t}+\alpha_{i}+\varepsilon_{i t} \\
& \text { Mathscore }=\beta_{0}+\beta_{2} P_{i t}+\beta_{3} X_{i t}+\beta_{4} W_{i t}+\alpha_{i}+\varepsilon_{i t}
\end{aligned}
$$

In the above equations, the dependent variables are the test score theta values computed from the LEAPS English, Urdu, and mathematics tests, respectively. ${ }^{6}$ The independent variable of interest, $P_{i t}$, is a dummy variable measuring whether a student undertakes private tuition. The other independent variables include child-level, household-level $\left(X_{i}\right)$, and schoollevel $\left(W_{i}\right)$ time-variant characteristics that might affect academic performance, such as whether the child receives help with his/her schoolwork at home, parents' perception of the child's intelligence, household wealth index, the STR in the child's school, and the infrastructure index for the school.

A fixed-effects model is fitted to account for unobserved individual characteristics, such as student motivation and ability, which might affect both learning outcomes and the demand for private tuition, making private tuition endogenous in the regression equation (Gurun \& Millimet, 2008). The fixed-effects estimator allows us to assess the within-individual impact of undertaking private tuition in a gains formulation.

In our sample, approximately 22 percent of students switched between undertaking and not undertaking private tuition in 2004, and 32 percent switched between these categories in 2005. One way to assess whether private tuition has an impact on the learning gap between private and public schools would be to include a variable measuring both public school attendance and tuition attendance in the regression equation. In

\footnotetext{
${ }^{6}$ Theta values were computed in the LEAPS data using item response theory and following international testing protocols. These theta values correctly account for the different difficulties of test questions in computing an overall score (Andrabi et al., 2007, pp. xiv).
} 
such a formulation, if the coefficient of the public school dummy becomes insignificant when private tuition is controlled for, one would conclude that private tuition explains much of the learning gap between public and private schools.

However, private tuition uptake and private school attendance in our data is highly correlated, so controlling for both would inevitably lead to one or the other variable becoming insignificant. Instead, we run separate fixed-effects regressions for private and public school attendees. We look only at those students who did not shift between schools during the period of analysis to ensure that the impact on academic performance is not confounded by school-switching behavior. The results imply that, if a private school student who takes up private tuition in a given year gains more from this tuition than his/her public school counterpart, then at the baseline public and private schools are equal in terms of academic performance and it is the additional year of private tuition that has led to the learning gap between the two groups.

\section{Results}

This section discusses the results obtained from our model.

\subsection{Determinants of Private Tuition}

\subsubsection{The Demand Side}

Table A1 in the Annex gives the demand-side determinants of the incidence of private tuition. The results largely confirm the findings of our descriptive analysis. As shown, public school students are less likely to engage in private tuition than their private school counterparts, even after controlling for child-level and household-level characteristics. The average marginal effect of switching from a private to public school for the same individual and across individuals is -0.317 .

The predicted probability of a public school student undertaking private tuition (keeping all the other variables at their mean value) is 15.7 percent, whereas it is 36.2 percent for private school students. Moreover, whether a child receives help at home with his/her schoolwork significantly decreases the child's likelihood of undertaking private tuition: those receiving help at home have a predicted probability of 15.4 percent and those not receiving help at home have a predicted probability of 36 percent. The average marginal effect of getting help at home for the same individual and across individuals is -0.802 . 
Schooling quality also affects private tuition uptake, but not in the direction one would expect. According to the random effects analysis, attending a school with a high STR leads to a higher probability of undertaking private tuition. This suggests that students supplement formal schooling with private tuition rather than using it as a substitute for poorquality schooling.

Gender and household wealth do not seem to have an impact on the demand for private tuition. This implies that there is no gender bias in tuition demand and that there are no equity issues involved in terms of access to paid tuition classes. However, we should make these inferences with caution, having specified neither the type of tuition undertaken (whether one-to-one classes or in a larger academy setting) nor the tuition provider (neighbors or mainstream teachers, etc.). The type of tuition class as well as the type of tutor has implications for the quality of tuition provided. It could be that students from a lower socioeconomic background attend lower-quality tuition classes offered by a neighbor or relative, which may have fewer benefits in terms of academic performance. Further investigation is needed to address this issue.

\subsubsection{The Supply Side}

Table A2 in the Annex gives the results of the random-effects estimation for the supply-side determinants of private tuition. The average marginal effect of teaching at a public school for the same individual and across individuals is -1.539 . This implies that private school teachers have a higher probability of offering private tuition than teachers in public schools. This is also evident from the descriptive analysis. Further, being a contract teacher positively affects the decision to provide private tuition. Studies show that contract teachers are paid a quarter of the salary paid to permanent teachers (Aslam, 2003; Das \& Bau, 2011), making it likely that these teachers supplement the meager income earned through mainstream schooling by engaging in the private tuition market.

A gender difference is also seen in the tutor labor market. Male teachers have a higher probability of providing private tuition than their female counterparts. In terms of teacher autonomy at school, the coefficient of the dummy variable measuring average autonomy in school is positive and significant, indicating that teachers with an average level of autonomy in school have a higher probability of providing private tuition than those with below-average autonomy. However, having above-average and extremely high levels of autonomy in school have no significant effect on 
the probability of providing tuition. In terms of teacher quality, as measured by teacher absenteeism and experience, there is no significant difference between tutors and nontutors. This indicates that the mainstream teachers who provide tuition do not shirk their duties during school hours to create the demand for their after-school tuition classes.

\subsection{Differential Impact of Private Tuition on Academic Performance for Public and Private School Students}

Before estimating the fixed-effects model, we perform a graphical analysis of the academic performance over time of switchers and nonswitchers. Figure 10 shows the trajectories of those students who stayed in public or private schools, respectively and (i) did not take up private tuition through the period of interest or (ii) took up private tuition in 2004, or (iii) took up private tuition in 2005.

The graphs show differing trajectories for public and private schoolchildren who took up private tuition during the period of analysis. In public schools, those students that took up private tuition in 2004 had higher test scores in 2003 than those who did not take up private tuition through the period of interest. In private schools, on the other hand, students who took up private tuition in 2004 started with lower test scores than those who did not take up private tuition in 2004.

This is in tandem with our analysis of the determinants of the demand for private tuition as it implies that, in public schools, students who are already performing well are more likely to take up private tuition to supplement their learning than weak students who take it up as remedial education. In private schools, which have a more competitive environment, students falling behind their peers may opt for private tuition as a form of remedial education. Students who take up private tuition in Grade 4 (2005) generally start with lower test scores than their counterparts both in private and public schools. For public schools, this indicates that consistently lowperforming students (near Grade 5) about to sit the Punjab Examination Commission exam take up private tuition to supplement their formal schooling and perform as well as their peers in the exam. 
Figure 10: Achievement over time for children who changed private tuition attendance
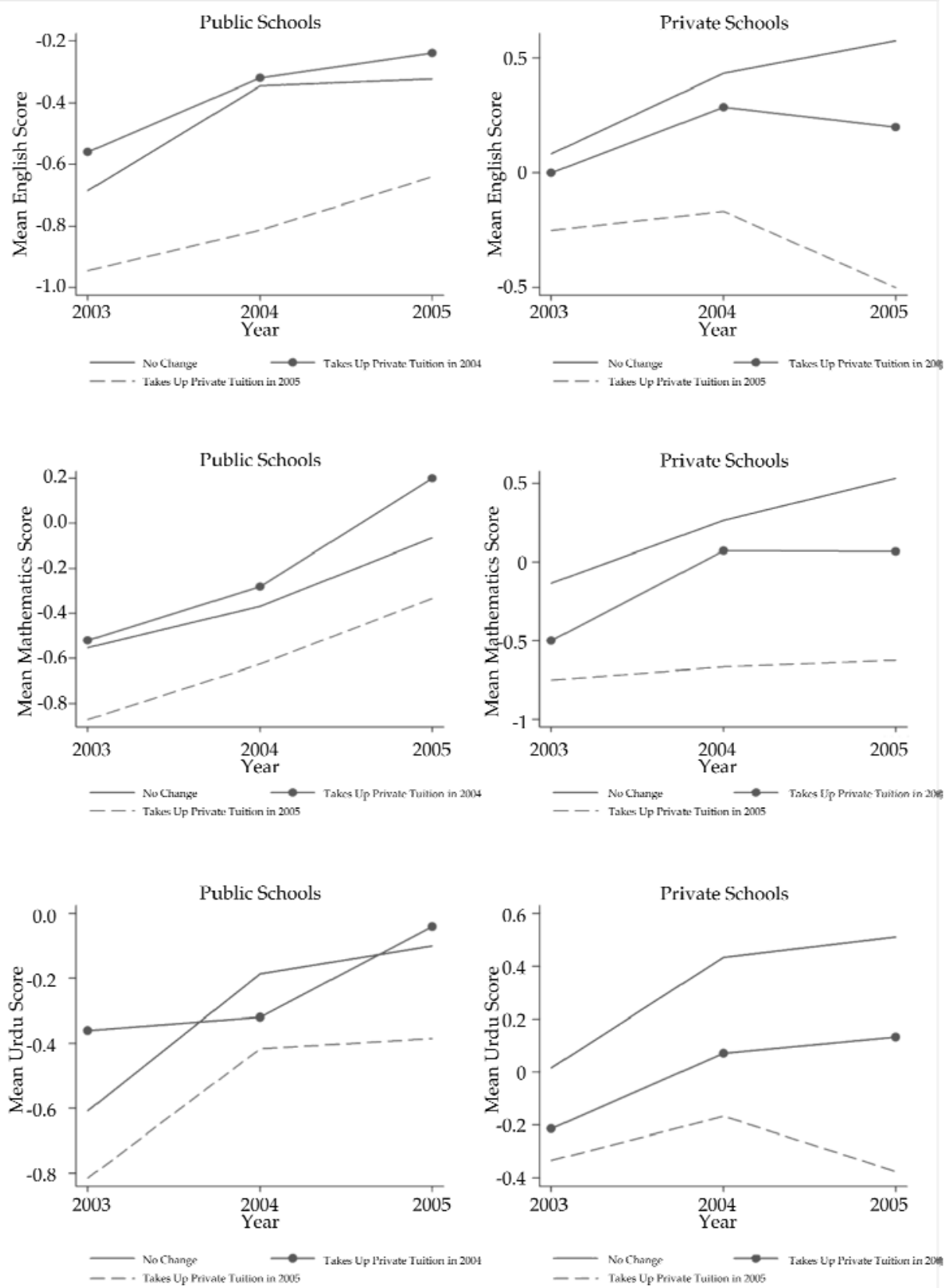

Source: LEAPS Data 2003 - 2005 
The slopes of the lines indicate a positive gain in academic performance for public school students who took up private tuition in 2004. Although test scores seem to rise over time even for those students who did not take up private tuition in any period, those who took up private tuition in 2004 face a starker rise, especially in 2005, suggesting positive gains from tuition that are realized with time. This is not the case for private school students, suggesting that private tuition has little impact on their academic performance. Further, both public and private school students who took up private tuition in 2005 gained little in terms of academic performance; private tuition even had a negative effect on the latter. However, this could be because the gains from tuition classes take time to be realized and, as the students were tested during half-term, they might not have fully realized these gains.

Thus, Figure 10 provides preliminary evidence for the gains from private tuition for public school students. However, unobserved factors affecting both academic performance and private tuition uptake can confound the results above. To control for this, we estimate a fixed-effects model, the results for which are given in Table A3 in the Annex. For a given public school student, private tuition has a positive significant impact on the student's mathematics and Urdu test scores and an insignificant impact on his/her English test score.

For a given private school student, the model yields the opposite result: private tuition uptake has a positive significant effect on the English test score and an insignificant effect on both the mathematics and Urdu test scores. Thus, for mathematics and Urdu, the learning gap between public and private school students remains even after accounting for private tuition since it does not significantly affect private school students' performance. This gap could, however, be bridged by providing tuition to public school students as these students gain significantly from such extra classes.

On the other hand, private tuition accounts for much of the learning gap between private and public schools in English test scores as private school students benefit significantly from private tuition while public school students do not. This is an interesting finding as the largest learning gap between public and private schools is in English (approximately 1.5 times more than in other subjects) (Das et al., 2006). This implies that, as private school students engage significantly more in private tuition than public school students, the gap might be considerably reduced once tuition is accounted for. 
Since the regression does not account for which subject the student is being tutored in, it could be that private school students take up tuition specifically in English whereas public schools students do not. Private schools tend to be English-medium schools and, prior to 2011 (and thus during the period of study), all public schools were Urdumedium. It is, therefore, highly plausible that this is the case since students might well need extra help to understand a curriculum delivered in English in private schools.

Figure 11 provides further evidence that private tuition uptake can serve to reduce the learning gap between public and private school students in mathematics and Urdu but not in English. Again, we consider only those students who did not switch between schools during the period of study. The red line maps the learning outcomes of private school students over time, the blue line shows the learning outcomes of public school students who started private tuition in 2004, and the green line shows the learning outcomes of public school students who started private tuition in 2005.

Figure 11: Learning gaps between private and public schools
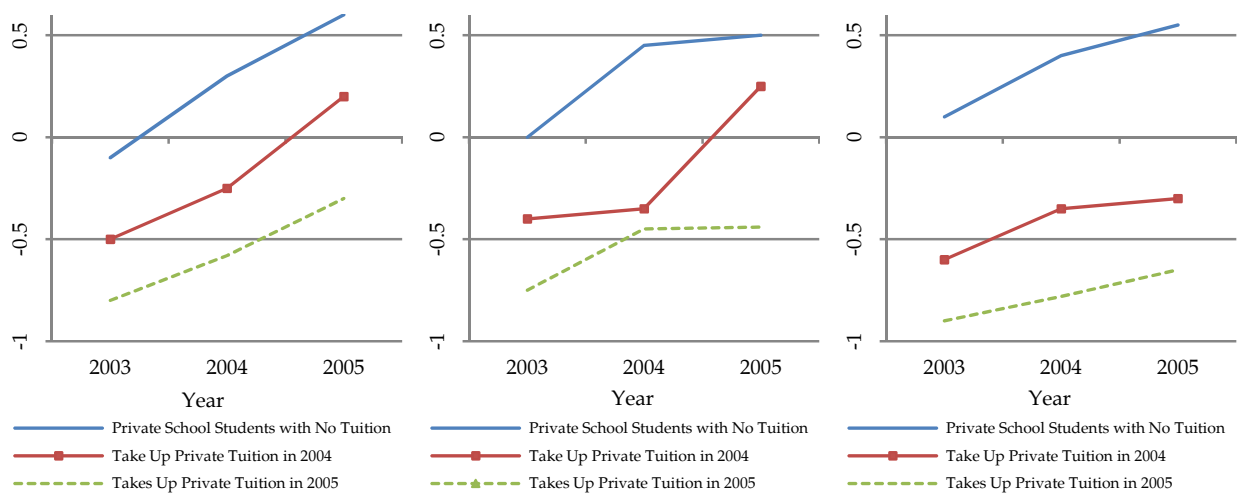

\section{Discussion and Concluding Remarks}

This study has established the strong presence of a third education sector in Pakistan: shadow education. Given that the data used is restricted to primary students in certain rural districts of Punjab, the prevalence of this sector is likely to have been underestimated as anecdotal evidence suggests a higher incidence of private tuition in urban areas and at secondary and upper levels of schooling (Aslam \& Mansoor, 2011). Overall, we find that the private tuition market is dominated by the private 
education sector: not only are private school students more likely to take up private tuition, private school teachers are also more likely to provide it.

As receiving help at home is negatively correlated with the demand for private tuition, the latter is also perceived as a substitute for parental help. This could be because parents do not have either the time or the knowledge to help their children and, hence, prefer to invest in private tuition instead. Private tuition is not seen as a form of remedial education, at least in public schools, where it is more common among highperforming students to supplement their learning. Further, it supplements quality formal schooling. This is indicated by the result that private school students (private schools being considered of a higher quality than public schools) have a higher probability of taking up private tuition; as the quality of the school rises (as measured by its STR), so does the probability of its students taking up private tuition.

On the supply side, private school teachers have a higher probability of providing private tuition than public school teachers. Contract teachers also have a higher probability of offering private tuition than permanent teachers. Given that both contract and private school teachers earn less than their public school counterparts, an opportunity to earn additional income could be what drives these teachers to engage in the private tuition market.

As shown in Section 3, a higher proportion of students take up private tuition with their own teachers at private schools, and from teachers at other schools in public schools. This could mean either that teachers at private schools do not deliver the expected level of effort in class, forcing their students to take up private tuition, or that these teachers deliver the same level of effort in class as those who do not provide private tuition and that after-school tuition simply complements the learning received during school hours.

We find evidence to support the latter claim as tutors and nontutors are not significantly different in terms of observable measures of teacher inschool performance. This suggests that tuition complements rather than substitutes for in-school learning and that banning private tuition will not increase the learning achieved during school hours but instead lead to a welfare loss as students will not benefit from the value addition that such classes give their academic performance. 
Our panel estimation provides significant evidence to support the claim that learning gaps between public and private schools cannot be attributed wholly to higher tuition incidence among private school students since private tuition does not add significant value to their inschool learning. However, such classes do add value for public school students and a combination of private tuition and public schooling might, therefore, help close the learning gap between public and private schools.

The main policy implication of this study is that the private tuition market should be regulated and made accessible to public school students, who would benefit most from such classes, allowing them to catch up with their private school counterparts. Further, since we have established that private tuition does not affect the in-class performance of mainstream teachers, banning it would not enhance welfare but lead to a net welfare loss instead. However, we need to keep in mind that we have not controlled for the different types of private tuition ranging from one-to-one sessions to larger classes at tuition academies. Whether one type is better than another and whether a certain type is driving the positive effects of private tuition, are questions that are left for future research.

Finally, this study has accounted only for primary school students, and the private tuition market dynamics may be considerably different for higher classes where such tuition is more prevalent. These dynamics need to be considered to effectively capture the demand and supply determinants of private tuition as well as to fully gauge the impact of tuition on academic performance. Evidence on the nature of private tuition needs to be explored to fully understand this rapidly growing third sector of education and to develop an appropriate policy toward it. This study is a step toward understanding the private tuition phenomenon and contributes to the literature by providing novel evidence on the workings of the private tuition market and its effect on public and private school dynamics. 


\section{References}

Andrabi, T., Das, J., \& Khwaja, A. I. (2002). The rise of private schooling in Pakistan: Catering to the urban elite or educating the rural poor? (Working paper). Cambridge, MA: Harvard University.

Andrabi, T., Khwaja, A. I., Vishwanath, T., \& Zajonc, T. (n.d.). Learning and educational achievements in Punjab schools (LEAPS) 2003-05 [Raw data].

Andrabi, T., Khwaja, A. I., Zajonc, T., \& Vishwanath, T. (2007). Pakistan: Learning and educational achievements in Punjab schools (LEAPS): Insights to inform the educational policy debates. Washington, DC: World Bank.

Annual Status of Education Report. (2013). Annual status of education report: ASER-Pakistan 2012. Lahore, Pakistan: Author.

Asankha, P. (2011). Demand for private tuition classes under the free education policy: Evidence based on Sri Lanka (MPRA Paper No. 31969). Munich, Germany: University Library of Munich.

Aslam, M. (2003). The determinants of student achievement in government and private schools in Pakistan. Pakistan Development Review, 42(4), 841-876.

Aslam, M. (2009). The relative effectiveness of government and private schools in Pakistan: Are girls worse off? Education Economics, 17(3), 329-353.

Aslam, M., \& Atherton, P. (2013). The shadow education sector in India and Pakistan: The determinants, benefits and equity effects of private tutoring (Mimeo). London, UK: Institute of Education, University of London.

Aslam, M., \& Mansoor, S. (2011). The private tuition industry in Pakistan: An alarming trend (Policy brief). Lahore, Pakistan: Annual Status of Education Report.

Barro, R. J., \& Lee, J.-W. (2010). A new dataset of educational attainment in the world, 1950-2010 (Working Paper No. 15902). Cambridge, MA: National Bureau of Economic Research. 
Benveniste, L., Marshall, J. H., \& Santibañez, L. (2008). Teaching in Lao PDR. Washington, DC: World Bank and Lao PDR Ministry of Education.

Bray, M. (2007). The shadow education system: Private tutoring and its implications for planners. Paris, France: International Institute for Educational Planning.

Bray, M. (2009). Confronting the shadow education system: What government policies for what private tutoring? Paris, France: International Institute for Educational Planning.

Bray, M., \& Lykins, C. (2012). Shadow education: Private supplementary tutoring and its policy implications for policymakers in Asia (Issue Brief No. 9). Manila, The Philippines: Comparative Education Research Centre, University of Hong Kong, and Asian Development Bank.

Bray, M., \& Silova, I. (2006). The private tutoring phenomenon: International patterns and perspectives. In Silova, V. Budiene, \& M. Bray (Eds.), Education in a hidden market place: Monitoring private tuition. New York, NY: Open Society Institute.

Cheo, R., \& Quah, E. (2005). Mothers, maids, and tutors: An empirical evaluation of their effect on children's academic grades in Singapore. Education Economics, 13(3), 269-285.

Dang, H. (2007). The determinants and impact of private tutoring classes in Vietnam. Economics of Education Review, 26(6), 683-698.

Dang, H., \& Rogers, F. H. (2008). The growing phenomenon of private tutoring: Does it deepen human capital, widen inequalities, or waste resources? World Bank Research Observer, 23(2), 161-200.

Das, J., \& Bau, N. (2011, November). Buy more, pay less: Measuring the performance of Pakistani contract teachers. Paper presented at NEUDC Conference, Yale University, New Haven, CT. Retrieved from <http://www.econ.yale.edu/conference/neudc11/papers/paper_ 116.pdf $>$.

Das, J., Pandey, P., \& Zajonc, T. (2006). Learning levels and gaps in Pakistan (Policy Research Working Paper No. 4067). Washington, DC: World Bank. 
Dawson, W. (2009). The tricks of the teacher: Shadow education and corruption in Cambodia. In S. P. Heyneman (Ed.), Buying your way into heaven: Education and corruption in international perspective (pp. 51-74). Rotterdam: Sense Publishers.

Glewwe, P., \& Kremer, M. (2006). School, teachers, and education outcomes in developing countries. In E. A. Hanushek \& F. Welch (Eds.), Handbook of the economics of education. Amsterdam: North-Holland.

Gurun, A., \& Millimet, D. L. (2008). Does private tutoring pay off? (Discussion Paper No. 3637). Bonn, Germany: Institute for the Study of Labor.

Ha, T. T., \& Harpham, T. (2005). Primary education in Vietnam: Extra classes and outcomes. International Education Journal, 6(5), 626-634.

Jacob, B. A., \& Lefgren, L. (2004). Remedial education and student achievement: A regression-discontinuity analysis. Review of Economics and Statistics, 86(1), 226-244.

Johnston, J., \& DiNardo, J. (1997). Econometric methods (4th ed.). New York, NY: McGraw-Hill.

Kang, C. (2007). Does money matter? The effect of private educational expenditures on academic performance (Working Paper No. 0704). Singapore: National University of Singapore, Department of Economics.

Lee, J.-T., Kim, Y.-B., \& Yoon, C.-H. (2004). The effects of pre-class tutoring on student achievement: Challenges and implications for public education in Korea. KEDI Journal of Educational Policy, 1(1), 25-42.

Lloyd, C. B., Mete, C., \& Sathar, Z. A. (2005). The effect of gender differences in primary school access, type, and quality on the decision to enroll in rural Pakistan. Economic Development and Cultural Change, 53(3), 685-710.

Silova, I. (2006). The private tuition phenomenon: International patterns and perspectives. In I. Silova, V. Budiene, \& M. Bray (Eds.), Education in a hidden market place: Monitoring private tuition. New York, NY: Open Society Institute. 
Tansel, A., \& Bircan, F. (2006). Demand for education in Turkey: A tobit analysis of private tutoring expenditures. Economics of Education Review, 25(3), 303-313.

Watson, L. (2008, December). Private expectations and public schooling: The growth of private tutoring in Australia. Paper presented at the Australian Association for Research in Education's National Conference, Brisbane, Australia.

Wooldridge, J. M. (2002). Basic linear unobserved effects panel data models. In Econometric analysis of cross-section and panel data (pp. 251-255). Cambridge, MA: MIT Press. 
Annex

Table A1: Determinants of the demand for private tuition

\begin{tabular}{|c|c|c|}
\hline & $\begin{array}{c}\text { (1) } \\
\text { Private tuition }\end{array}$ & $\begin{array}{c}\text { (2) } \\
\text { lnsig2u }\end{array}$ \\
\hline child_female & $\begin{array}{l}-0.0629 \\
(0.115)\end{array}$ & \\
\hline class & $\begin{array}{l}-0.0252 \\
(0.142)\end{array}$ & \\
\hline age & $\begin{array}{r}0.117 \\
(0.260)\end{array}$ & \\
\hline age $^{2}$ & $\begin{array}{r}-0.00872 \\
(0.0123)\end{array}$ & \\
\hline helpathome & $\begin{array}{r}-0.802^{* * *} \\
(0.126)\end{array}$ & \\
\hline _Iperceived_2 & $\begin{array}{l}-0.692 \\
(1.035)\end{array}$ & \\
\hline _Iperceived_3 & $\begin{array}{r}-0.276 \\
(1.011)\end{array}$ & \\
\hline _Iperceived_4 & $\begin{array}{r}-0.277 \\
(1.012)\end{array}$ & \\
\hline _Iperceived_5 & $\begin{array}{l}-0.629 \\
(1.032)\end{array}$ & \\
\hline ch2_heightzscore & $\begin{array}{r}-0.0206 \\
(0.0352)\end{array}$ & \\
\hline pubschool & $\begin{array}{r}-0.317^{* *} \\
(0.143)\end{array}$ & \\
\hline STR & $\begin{array}{l}-0.00499^{*} \\
(0.00281)\end{array}$ & \\
\hline basicinfindex & $\begin{array}{r}0.0456 \\
(0.0747)\end{array}$ & \\
\hline hhldwealth & $\begin{array}{r}0.0249 \\
(0.0398)\end{array}$ & \\
\hline Constant & $\begin{array}{r}-0.789 \\
(1.730)\end{array}$ & $\begin{array}{r}-1.465^{* * *} \\
(0.528)\end{array}$ \\
\hline Observations & 1,574 & 1,574 \\
\hline Number of childcode & 718 & 718 \\
\hline
\end{tabular}

Notes: Time effects and village fixed effects not included to save space. Marginal effects; robust standard errors in parentheses. ${ }^{* * *}=\mathrm{p}<0.01,{ }^{* *}=\mathrm{p}<0.05,{ }^{*}=\mathrm{p}<0$.

Source: Authors' estimation using LEAPS data (2003-05). 
Table 2: Determinants of the supply of private tuition

\begin{tabular}{|c|c|c|}
\hline & $\begin{array}{c}\text { (1) } \\
\text { Give tuition }\end{array}$ & $\begin{array}{c}(2) \\
\text { lnsig2u }\end{array}$ \\
\hline \multirow[t]{2}{*}{ experience } & -0.0195 & \\
\hline & $(0.0377)$ & \\
\hline \multirow[t]{2}{*}{ male } & $1.109^{* * *}$ & \\
\hline & $(0.356)$ & \\
\hline \multirow[t]{2}{*}{ pubschool } & $-1.539^{* * *}$ & \\
\hline & $(0.515)$ & \\
\hline \multirow[t]{2}{*}{ lsalary } & -0.527 & \\
\hline & $(0.333)$ & \\
\hline \multirow[t]{2}{*}{ contract } & $1.815^{* * *}$ & \\
\hline & $(0.427)$ & \\
\hline \multirow[t]{2}{*}{ married } & 0.177 & \\
\hline & $(0.369)$ & \\
\hline \multirow[t]{2}{*}{ age } & -0.158 & \\
\hline & $(0.103)$ & \\
\hline \multirow[t]{2}{*}{ agesq } & 0.000819 & \\
\hline & $(0.00150)$ & \\
\hline \multirow[t]{2}{*}{ localteach } & -0.472 & \\
\hline & $(0.296)$ & \\
\hline \multirow[t]{2}{*}{ _Idecisionm_2 } & $-0.437^{*}$ & \\
\hline & $(0.259)$ & \\
\hline \multirow[t]{2}{*}{ _Idecisionm_3 } & -0.317 & \\
\hline & $(0.455)$ & \\
\hline \multirow[t]{2}{*}{ _Idecisionm_4 } & -0.492 & \\
\hline & $(0.476)$ & \\
\hline \multirow[t]{2}{*}{ absenteeism } & 0.0264 & \\
\hline & $(0.0540)$ & \\
\hline \multirow[t]{2}{*}{ Constant } & 3.469 & $1.219^{* * *}$ \\
\hline & $(2.931)$ & $(0.358)$ \\
\hline Observations & 2,344 & 2,344 \\
\hline Number of teachercode & 1,470 & 1,470 \\
\hline
\end{tabular}

Note: Time effects and village fixed effects not included to save space. Marginal effects; robust standard errors in parentheses. ${ }^{* * *}=\mathrm{p}<0.01,{ }^{* *}=\mathrm{p}<0.05,{ }^{*}=\mathrm{p}<0.1$.

Source: Authors' estimation using LEAPS data (2003-05). 
Table 3: Impact of private tuition on academic performance: Fixedeffects estimation

\begin{tabular}{lrrr}
\hline & $\begin{array}{c}(\mathbf{1}) \\
\text { UrduScore }\end{array}$ & $\begin{array}{c}(\mathbf{2}) \\
\text { EnglishScore }\end{array}$ & $\begin{array}{c}(\mathbf{3}) \\
\text { MathsScore }\end{array}$ \\
\hline Public schools & & & \\
Private tuition & $361.9^{*}$ & -111.4 & $334.8^{*}$ \\
& $(186.4)$ & $(175.7)$ & $(189.6)$ \\
Constant & $-481.2^{* *}$ & $-408.0^{*}$ & -280.0 \\
& $(230.9)$ & $(244.0)$ & $(256.8)$ \\
Observations & 1,146 & 1,146 & 1,146 \\
R-squared & 0.115 & 0.086 & 0.106 \\
Number of childcode & 551 & 551 & 551 \\
\hline Private schools & & & \\
Private tuition & -38.76 & $348.8^{*}$ & 192.6 \\
& $(249.3)$ & $(201.7)$ & $(232.1)$ \\
Constant & $-750.3^{* *}$ & $-749.0^{* *}$ & $-436.8^{*}$ \\
& $(293.7)$ & $(308.0)$ & $(255.5)$ \\
Observations & 431 & 431 & 431 \\
R-squared & 0.199 & 0.138 & 0.220 \\
Number of childcode & 215 & 215 & 215 \\
\hline
\end{tabular}

Note: Other independent variables suppressed (including time effects). Robust standard errors in parentheses (clustered at the village level). $* * *=\mathrm{p}<0.01,{ }^{* *}=\mathrm{p}<0.05,^{*}=\mathrm{p}<0.1$.

Source: Authors' estimation using LEAPS data (2003-05). 